\title{
Perspectives on written L1 in Swedish CLIL education
}

\author{
Elisabeth Ohlsson, University of Gothenburg
}

\begin{abstract}
This article presents a longitudinal investigation of texts written by students in upper secondary schools in Sweden. The texts are collected at three different schools implementing Content and Language Integrated Learning, CLIL, where school subjects are taught in a second or foreign language, L2, in this case English. CLIL research with an $L 1$ focus in the Swedish context is rare. The present study explores and compares vocabulary use in texts written in L1 Swedish by students attending schools where English is used as the medium of instruction to various degrees, thereby representing diverse CLIL models. One school uses English in practically all subjects except in language arts (subject area of Swedish and optional German/French/Spanish). The other two schools use L2 English in some lessons but not all, thus representing other CLIL models. The data comprises 306 pieces of texts that were analysed using quantitative and corpus linguistic methods to examine the vocabulary use including linguistic variables connected to academic writing. The texts were written at four different occasions during a period of three years, Results indicate that the L1 vocabulary use concerning specific word variables show no substantial diversifications between the three CLIL schools despite the dissimilar exposure to L2 English and L1 use. The impact of L2 on students' L1 is sometimes raised as an apprehension against CLIL education in Sweden. The results regarding productive written academic vocabulary of the present study indicate that there are no grounds for such concerns.
\end{abstract}

Keywords: CLIL, upper secondary education, text linguistic variables, academic writing, L1

\section{Introduction}

During the last two decades, Content and Language Integrated Learning, CLIL, where non-language subjects are taught through a second or a foreign language (both referred to as L2 in this text) has increased in popularity in Sweden (Swedish National Agency for Education 2018; Sylvén, 2019; Yoxsimer Paulsrud, $2014,2019)$. However, there is nearly no stated policy regarding CLIL in Sweden compared to other countries (e.g., Nikula et al., 2013; Sylvén, 2013, 2018, 2019; Yoxsimer Paulsrud, 2014). There are minor regulations in Sweden regarding CLIL education for younger children but when education becomes optional, after the age of 16, there are no regulations at all at a national policy level. In other words, there is nothing that, for example, regulates the extent of lessons in

Corresponding author's email: elisabeth.ohlsson@gu.se eISSN: 1457-9863

Publisher: University of Jyväskylä, Language Campus

(C) 2021: The authors

https://apples.journal.fi

https://doi.org/10.47862/apples.98178 
L1 and L2, the teachers' target language proficiency, or in-service teacher training (Swedish National Agency for Education 2018). Upper secondary schools in Sweden offering this type of educational practices need permission to start but are then free to organize the CLIL programs as they please as long as they follow the Swedish national curriculum (Lgy11, Swedish National Agency for Education, 2011). This means that CLIL education in Sweden varies both within schools and between schools, leading to idiosyncratic models with a difference in exposure to both the target language and the L1. The implications different CLIL models might have on L1 productive writing is the object of interest here due to few prior studies in the Swedish school context and the fact that the existing studies are based on very limited samples.

Research on CLIL education in Sweden was noticeably infrequent before the longitudinal project Content and Language Integration in Swedish Schools, CLISS'. The aim of the project was to study CLIL in the Swedish context with a special focus on "students' proficiency and progress in written academic language, in both English and Swedish" (Sylvén, 2019, p. 9). Investigations with a focus on the improvement of target language proficiency, here L2 English, had been performed in few dissertations before the project (Sylvén, 2004; Washburn, 1997) and only one study has focused on CLIL students' development in L1 Swedish compared to non-CLIL (Lim Falk, 2008).

The purpose of this article is to contribute to the CLIL research field with solid, empirical data where the possible influence of CLIL, in L2 English, on students' productive written L1 Swedish, is investigated. The aim is to examine the vocabulary use in texts written in L1 Swedish by students attending different CLIL schools in relation to these schools' specific use of L2 English and L1 Swedish, respectively.

The study is guided by the following research questions:

- Are the differences in the scope of instruction in L2 English at the three CLIL schools reflected in the L1 Swedish writing regarding productive academic vocabulary in students' texts, and if so, in what ways?

To elucidate the text analyses, a background to CLIL, CLIL in Sweden, and CLIL and L1 research is firstly presented, followed by a brief outline of vocabulary learning with an emphasis on linguistic variables characteristic for academic prose. Information about the schools, the students and the texts follows thereafter and the methods used to investigate the texts are then presented. Finally, the results are described and discussed in relation to the research questions and related aspects.

\section{Background}

\subsection{CLIL in Europe}

The growth of CLIL schools in Europe is associated to the pursuit of consensus on language education within the European Union. Since the early 1990s different bilingual teaching projects have been supported by the EU and as a result the European Commission formulated an Action Plan 2004-2006 (COM/2003/449). It was stated that improvements regarding language teaching and learning were required from the member states and efforts should "make sure that everyone 
can speak two languages as well as their mother tongue" and to "create a more language-friendly environment in Europe, a Europe which really makes the most of its wealth of languages" (COM/2003/449, 2004, p. 3). One chapter in the Action Plan is devoted to CLIL education and concerns funding, increased support to schools wishing to introduce a CLIL approach and promoting collection of available data for research from this kind of language education (COM/ 2003/449, 2004, p. 19).

The implementation of CLIL education throughout Europe is linked to national policy level where there are key differences in contexts which at times can be related to political governance. Coyle (2005 p. 2) claims that there is not just one model for CLIL but the "different models all share the common founding principle that in some way the content and the language learning are integrated". The diversity of CLIL education is discussed in research overviews and anthologies (e.g., Dalton-Puffer et al., 2014; Nikula et al. 2013; Pérez-Canãdo, 2012; Ruiz de Zarobe, 2013; Sylvén, 2013, 2018).

In Austria and Sweden, there are no national guidelines for CLIL and the implementation has rather been more of a grass roots movement (Dalton-Puffer, 2011; Sylvén, 2018). In these two countries expectations of CLIL teachers' language competence come from stakeholders rather than authorities, and teachers who are native English speakers do not need a teacher certificate in Swedish upper secondary schools (Dalton-Puffer, 2007; Sylvén, 2018, 2019; Yoxsimer Paulsrud, 2014). This is in contrast to Finland where there are high demands on the CLIL teachers' language competences in the target language which also corresponds with the linguistic demands on CLIL teachers in the Netherlands (Sylvén 2018, p. 9, 13). In Germany, as in Spain, the regulations regarding CLIL education vary due to regional self-governance, though some general principles exist (e.g., Coyle, 2007; Sylvén, 2013). Diverse CLIL contexts with dissimilar conditions and regulations do, of course, have an impact on comparisons between research studies, which leads to a need for more research where homogeneity of the samples is sought (e.g., Navarro-Pablo \& López Gándara 2019; Pérez Cañado, 2018, 2020).

\subsection{CLIL in Sweden}

CLIL was first introduced in Sweden in 1977, by an individual teacher using English as the medium of instruction in a vocational program (Sylvén, 2013, 2019). In 1989, a new amendment on school organization was decided which took place in 1991. In 1994, new national curricula were implemented for both compulsory and upper secondary school (Government Bill 1989/90:41; Government Bill 1992/93:220). This changed the school governance from a state school system to municipalities being in charge of the education and since then the municipalities have an extensive right of decision on how schools are organized. In addition to this, independent schools were introduced. The amendment also included a replacement of the school government from the stately Swedish National Agency to the semi-independent Swedish National Agency for Education. English became a mandatory subject from primary school throughout the nine years of compulsory school. The changes in governance led to a quest for profiling among schools where the use of English as the medium of instruction was a strong incentive. Many schools perceived the attraction to English and English culture amid young people to correlate with exposure to 
English outside school (Sundqvist, 2009; Yoxsimer Paulsrud, 2014). Some schools, municipal as well as private, independent organizers of schools, used this popularity of 'everything English' in their campaigns to gain more applicants.

In 2001, approximately 20 percent of all Swedish schools at upper secondary level and 4 percent at lower secondary level implemented CLIL to a varying extent (Sylvén, 2013, p. 303). In 2012, the corresponding approximation for CLIL education was 27 percent at upper secondary level (Yoxsimer Paulsrud, 2014, p. 71). IB-schools (International Baccalaureate) are not included in these figures as they have their own international curriculum and rules in contrast to mainstream CLIL education, which follows the national curriculum and control documents linked to the country where it operates.

Parallel to this amendment on school organization among comprehensive schools and independent schools and the special status of English in Swedish society, a national language law was completed, The Swedish Language Act (SFS, 2009:600). It was prepared from the late 1990s by a parliamentary committee (SOU 2002:27) and raised a great extent of public discussion in the early 2000s. A fear of domain loss in Swedish due to the dominance of English was expressed. Several reports with a special focus on CLIL education and results from previous international studies in the field were written at the request of the Swedish National Agency for Education (1997, 2000, 2001a, 2001b). In 2018, a special report concerning education in English was published by the Swedish National Agency for Education where a governmental investigation was urged to inquire into the unregulated part of CLIL education. The report also examined the impact on Swedish and domain specific knowledge which is still referred to as a 'possible risk' for the development of the L1 and content knowledge, despite the very limited research with this focus.

A growing interest in CLIL education in Sweden as well as an increasing number of schools offering CLIL programs and thereby, an increased use of a foreign language as the medium of instruction, has led to the question of the roles of language learning regarding the L1, L2 or L3 (e.g., Lim Falk, 2015). In the CLISS project, an overall focus was on effects of CLIL on written academic language, both in English and in Swedish. The data collections in the project were vast and include both quantitative and qualitative data such as a student background questionnaire, a motivation questionnaire, vocabulary tests, reading comprehension and essay writing, all in both Swedish and English. Interviews with students and teachers were made, as were classroom observations (Sylvén, 2019, pp. 9-15). The collected data from both CLIL and non-CLIL classes have been explored by the project members studying various aspects of CLIL (see Sylvén, 2019). In connection with the CLISS project, four reports have also been written at the request of the Swedish National Agency for Education. These reports sum up some of the results regarding CLIL education in Sweden, background factors and grades, comparisons of texts written in Swedish and in English regarding text structure, and one of them provides a follow-up study of both CLIL and non-CLIL students after their three years of upper secondary education (Apelgren, 2018; Apelgren \& Holmberg, 2018; Olsson \& Sylvén, 2018; Sylvén, 2018).

CLIL is sometimes disputed to be selective and lack egalitarianism (e.g., Bruton 2015; Cenoz et al., 2014; de Dios Martínez Agudo, 2020; Lorenzo et al., 2021). In Sweden education is free of charge and the CLIL schools in this study are all municipality upper secondary schools to which any student can apply. At 
this level, entrance to any educational program is achieved by grade selection. This means that any student, for instance those with a special interest in languages, can apply to CLIL programs regardless of background factors and hence contribute to social inclusion and equity (e.g. Pérez Cañado 2020, p. 11). The student group in this study is not homogenous regarding SES (see Apelgren 2019, Ohlsson 2021). Two of the participating schools also have a non-CLIL strand, offering opportunities to compare education with different languages of instruction in the same school context.

\subsection{CLIL and L1}

In the early immersion programmes in Canada in the 1960s, evaluations of the content learnt in an L2 and the development of L1 as well as L2 were made continuously (Swain \& Lapkin, 1981). The results from these "immersion data" (Navés, 2009, p. 23) show that although good performance in most language skills was obtained there were deficits as regards grammar competence and vocabulary in the L2.

Research on L1 and CLIL education covers different aspects; one is the use of L1 to scaffold the L2 communication in CLIL classrooms both orally and in writing (Lasagabaster, 2017; Lin, 2015; Martínez-Adrián et al., 2019; Pavón Vázquez \& Carmen Ramos Ordóñez, 2019; Yi Lo, 2015). Nikula and Moore (2019, p. 237) advocate that "the L1 should be appreciated as a potentially valuable tool in bilingual learning situations". Furthermore, they discuss the concept of translanguaging in relation to bilingual talk in CLIL classrooms (Nikula \& Moore, 2019 , p. 242). This is also conferred by Lasagabaster and Garcia (2014) when they argue for "the benefits of implementing a planned use of bilingual translanguaging into educational contexts [...]" (Lasagabaster \& Garcia, 2014, p. 7). Classroom practices were investigated in the CLISS-project by Yoxsimer Paulsrud (2014, p. 140). In the three CLIL schools referred to in this study, language alternation, i.e. the use of English and Swedish, can be planned and strategic or temporary as scaffolding or unplanned and "should be understood as intertwined" and a "potentially positive strategy" (Yoxsimer Paulsrud, 2014, p. 180).

There are also studies that instead of functions of L1 have focused on comparing CLIL groups to those studying through L1. In Lim Falk's (2008) ethnographical study of one CLIL and one non-CLIL class in Sweden, the CLIL students $(n=25)$ outperformed the non-CLIL $(n=19)$ students in L1 Swedish regarding text length, but the non-CLIL class communicated orally far more during lessons (in L1 Swedish), both in the subject area of Swedish and in other subjects where more subject related language also was used. Written L1 examined within the study was not affected, though few CLIL students used subject specific language (Lim Falk, 2008, p. 274).

A large-scale study in Finland with CLIL and non-CLIL students at primary level explored if bilingual education would hinder students' learning in both their L1 and the L2. Another goal was to see if CLIL could affect the development of literacy skills in L1 and L2 of primary CLIL students in a negative manner. The main results showed no such indications (Merisuo-Storm, 2006).

An additional large-scale study was conducted in Spain with students at primary and secondary level, in both rural and urban settings. The aim was to compare CLIL and non-CLIL learners' development, knowledge and skills in 
their L1 (Navarro-Pablo \& López Gándara, 2019). The study included 271 students (134 CLIL, 137 non-CLIL) and 38 teachers. The groups were matched for verbal intelligence, motivation and out-of-school exposure to English by using different tests in order to create a homogenous sample of students allowing for comparisons. Results showed positive effects for the CLIL learners, regardless of age and setting. The results also indicated that CLIL had a positive impact on students' understanding of how language works and the L1 or foreign language was used by the teachers depending on the level of difficulty of the content and on students' foreign language competence (Navarro-Pablo \& López Gándara, 2019, p. 11). The results remained consistent as a whole with significantly better results for the CLIL students, irrespective of educational level, strands and the different schools (Navarro-Pablo \& López Gándara, 2019, p. 12). The researchers therefore argue that L1 and foreign language competences both can, and should, progress in parallel and benefit each other.

Also the CLISS project looked into productive written academic L1. The texts were written on eight occasions during the project (four essays in English and four in Swedish, see table 2). As regards the vocabulary tests there was "no indication of a disadvantage in terms of Swedish vocabulary development among L1 CLIL students $(n=140)$ compared to non-CLIL students $(n=84)$ " (Lindberg \& Johansson 2019, p. 255). Nor were significant differences found in another sub-study between CLIL $(n=147)$ and non-CLIL $(n=90)$ students' performances in the examination of certain linguistic features in 520 texts written in Swedish (Ohlsson 2018). Here text length, word length, word variation index, long words, high- and low frequent words, nominalizations, verbs in the passive tense and academic words were analyzed (Johansson \& Ohlsson 2019, Ohlsson 2018). In an analysis of both English and Swedish texts $(\mathrm{N}=320)$ with a focus on text structure, no connection to the language of instruction was detected in texts written by 25 CLIL students and 15 non-CLIL students (Apelgren \& Holmberg, 2018, p. 33). In three of the studies (Holmberg, 2019; Lim Falk, 2019; Lim Falk \& Holmberg, 2016) the Swedish texts were selected from two of the four occasions $(n=260)$. The results indicated that L1 production was poorer at the one school where English was used almost exclusively as the medium instruction compared to the other two CLIL schools, where English and Swedish were used in parallel.

It can thus be concluded that the relationship between CLIL and students' L1 merits further scholarly attention, which is the focus of the present study.

\section{Academic language features and academic writing}

Language learning in general includes many aspects. This article has its focus on words and language features associated with writing in an academic text genre. There is no single definition of the language used in school in reading and writing, as the 'language of schooling' differs from the everyday language used outside school (e.g., Schleppegrell, 2004; Snow \& Ucelli, 2009). The complexity of defining academic language explicitly is connected to its "lexical, grammatical and discursive features" (Fang \& Park, 2019, p. 1). Snow (2010, p. 450) describes the most frequently noted features as "conciseness, avoiding redundancy, using a high density of information-bearing words, precision of expression and relying on grammatical processes to compress complex ideas into few words". Myhill 
(2018, p. 12) and her fellow researchers argue for the notion of 'how language choices shape meaning' and that it is more essential to realize what happens in a text when using a passive construction than knowing that it is a passive construction, using the expression 'grammar as choice' (cf. Carter \& McCarthy, 2006, p. 7). The significance in recognizing academic language skills as more comprehensive than only concerning a certain age group of learners or only vocabulary is of utmost importance especially in early school years as a continuum to build on earlier language learning (e.g., Fang \& Park, 2019; Schleppegrell, 2004; Snow, 2010; Snow \& Ucelli, 2009; Uccelli et al., 2015).

Academic vocabulary in this study is defined as linguistic variables characteristic of academic writing such as nominalizations, verbs in the passive tense and low frequent words as examples of lexical and grammatical features and text complexity. These variables are possible to identify and examine in students' texts written in Swedish by using corpus linguistic methods and lexical profiles (Anthony 2014; Biber et al., 2006; McEnery et al., 2006). Nation (2013, p. 18) uses four word categories in written academic texts by looking at representation, frequency and dispersion of; high-frequency words (function words and common content words), academic words (frequent in academic texts), technical words (closely related to a subject area) and low-frequency words (uncommon words). Schmitt (2010, p. 307) even describes the importance of corpus resources as: "[...] it is probably not too extreme to say that most sound vocabulary research will have some corpus element."

\section{Material and methods}

\subsection{The schools and the students}

The students (age 16-19), attended five different CLIL classes at three upper secondary schools, A, B and C (see table 1). School A is an international school in a city context, offering both CLIL and IB, International Baccalaureate, with students from early ages in primary school to the upper secondary level. The study was conducted in the CLIL part of the school. Schools B and C are municipal upper secondary schools in urban settings, covering preparatory programs for higher education as well as vocational programs, including a CLIL strand and mainstream non-CLIL groups coexisting in each grade. The focus in this article is on the CLIL students at the three different schools as a continuation of a previous study (see Ohlsson, 2018). The CLIL classes at schools A, B and C were all from programs which are preparatory for higher education and included programs for Economics, Social Science and Natural Science. School A uses English as the language of instruction almost exclusively in the non-language subjects which makes the education more or less monolingual. The students also often speak English during breaks. In contrast, the CLIL classes at school B and $C$ use both English and Swedish, in parallel, as languages of instructions in most subjects except in language arts and the students often communicate in Swedish outside the classrooms. At school B, the CLIL education is more structured with planned full class instructions in English. School C was occasionally affected by external factors such as change of group compositions in the schedule, mixing CLIL and non-CLIL students leading to more use of the L1 than intended. All three schools are free of charge, students make an active choice and the 
admission is based on grades, as to all upper secondary education in Sweden. The analyses of the background questionnaire in the project show that the CLIL-group is not homogeneous; the grade point average when starting upper secondary school had a wide range so there were some students with higher grades but also several with lower grades, $25 \%$ of the students at school A were born outside Sweden, compared to $5 \%$ at school B and $8 \%$ at school C. The parental educational background was higher in the CLIL group than in the non-CLIL group but this also differed between the three CLIL schools (see Apelgren, 2018, 2019).

Table 1 illustrates the different classes participating in this study; one Economy class at school C, two Social Science classes, one at school A and one at school C and lastly two Natural Science classes, one at school A and one at school B. When reporting the results in this article, classes have been collapsed, so each school is considered as one unit due to the statistical calculations regarding sub groups, which would otherwise have been too small.

Table 1. Participating schools and classes and numbers of participating students.

\begin{tabular}{lcccccc}
\hline Program & $\begin{array}{c}\text { School A } \\
\text { Number of } \\
\text { students }\end{array}$ & $\begin{array}{c}\text { A } \\
\text { Female/ } \\
\text { Male }\end{array}$ & $\begin{array}{c}\text { School B } \\
\text { Number of } \\
\text { students }\end{array}$ & $\begin{array}{c}\text { B } \\
\text { Female/ } \\
\text { Male }\end{array}$ & $\begin{array}{c}\text { School C } \\
\text { Number of } \\
\text { students }\end{array}$ & $\begin{array}{c}\text { C } \\
\text { Female/ } \\
\text { Male }\end{array}$ \\
\hline Economics CLIL & & & & & 19 & $15 / 4$ \\
\hline Social Sciences CLIL & 37 & $26 / 11$ & & & 28 & $20 / 8$ \\
\hline Natural Sciences CLIL & 30 & $19 / 11$ & 33 & $23 / 10$ & & \\
\hline $\begin{array}{l}\text { Total number of students } \\
\text { at schools A, B and C }\end{array}$ & 67 & & 33 & & 47 & \\
\hline
\end{tabular}

The number of CLIL students in this study was 147 (103 female and 44 male). Results for all participating classes and individuals (males and females, CLIL and non-CLIL) are not described in this article (but see Ohlsson, 2018, 2021).

\subsection{The texts}

The texts in Swedish $(\mathrm{N}=306)$ were written as assignments on four different occasions during a period of three years (table 2). This provided an opportunity to compare and explore if progress had been accomplished regarding academic writing by the participating schools, classes and individual students. It also enabled an investigation into any possible impact of the diverse CLIL settings on students' L1 Swedish writing.

The assignments, in Swedish and English, were constructed by two of the senior project members and were modelled to resemble the National Test Essays which are mandatory in Swedish schools. In the subject area of Swedish, these national tests are carried out every third year for the students, through compulsory school and on two occasions in upper secondary school. The text types, argumentative and expository texts, and the topics, were selected to correspond with the subject goals of the existing curriculum and syllabi for the upper secondary school system (Lgy11, Swedish National Agency for Education, 2011, see table 2). Thus, the participating students were familiar with the expected demands. The time limit for writing the project assignments was 90 minutes. Teachers were not informed about the topics beforehand in order to 
secure validity and equity. The tasks were constructed so the factor of difficulty would be similar in all assignments to make it possible to examine any progress between the first assignment written during the students' first term and the last assignment, written term five out of six during the last year of the students' upper secondary period. This was achieved through a long experience from the senior constructors working closely with the team designing the National Test Essays. Throughout the three years, a project member was always present at each data collection to enhance the validity by giving the same general framing and instructions before the tests.

The students wrote their texts on computers and sent them to the project data base, each coded with an individual number. All in all during the three project years, the students wrote eight assignments, four in English and four in Swedish. The English texts have been analyzed by Olsson $(2015,2016)$ and Olsson and Sylvén $(2015,2019)$ and the texts in Swedish have been investigated by Holmberg (2019), Lim Falk (2019), Lim Falk \& Holmberg (2016) and Ohlsson (2018).

In table 2 the number of texts written by the CLIL students is shown as are the topics of each assignment in the subject area of Swedish with the numbers of the participating groups at schools $\mathrm{A}, \mathrm{B}$ and $\mathrm{C}$.

Table 2. Number of participants and topics of assignments in Swedish at the four different occasions.

\begin{tabular}{ccccc}
\hline Assignments & $\begin{array}{c}\text { Assignment 1 } \\
\text { Term 1/2 } \\
\text { (expository) } \\
\text { Health and } \\
\text { Wealth }\end{array}$ & $\begin{array}{c}\text { Assignment 2 } \\
\text { Term 3 } \\
\text { (argumentative) } \\
\text { Car-free City }\end{array}$ & $\begin{array}{c}\text { Assignment 3 } \\
\text { Term } \mathbf{4} \\
\text { (expository) } \\
\text { Public Health }\end{array}$ & $\begin{array}{c}\text { Assignment 4 } \\
\text { Term } \mathbf{5} \\
\text { (argumentative) } \\
\text { Completely Shared } \\
\text { Participtal Leave }\end{array}$ \\
\hline School A & $\mathbf{N = 8 0}$ & $\mathbf{N = 8 4}$ & $\mathbf{N = 7 5}$ & $\mathbf{N = 6 7}$ \\
$\mathbf{B}$ & $\mathbf{5 4} \%$ & $57 \%$ & $51 \%$ & $45 \%$ \\
$\mathbf{C}$ & 26 & 26 & 23 & 22 \\
\hline
\end{tabular}

As is often the case with school-based studies, the participating students were not always present in school. There was only one specific opportunity to write each assignment and if a student was absent during that precise lesson, another opportunity was not arranged, for practical reasons. The CLIL student attendance for the written assignments in Swedish was between 45 percent and 57 percent which is described in table 2 above.

\subsection{Methods}

The methods used in this study to identify, describe and analyze the students' productive vocabulary in the written assignments are shown in table 3 . This study has a quantitative approach which makes it possible to investigate a larger material of texts. The analyses were made by copying and pasting the 306 texts into a web-based tool; the LIX calculator ${ }^{2}$ which gives an immediate calculation of quantitative measures, here text length, word length, words longer than six 
letters and word variation index. In addition, AntWordProfiler's, a freeware tool for profiling the vocabulary level and the complexity of texts was also used (Anthony, 2014; Nation \& Anthony, 2016). The online version contains some of the most common words in English distributed over three frequency bands. By extracting word tokens in Swedish from a text corpus with 80 million words (Blog mix, 2012) a special frequency-based list of 5000 of the most common words in Swedish, distributed over five frequency bands, was made and the English data removed. This made it possible to explore to what degree the students' vocabulary contained general words or if, and to what extent, they use low-frequency words that might represent a general academic vocabulary (Johansson \& Ohlsson 2019).

In addition to quantitative measures, corpus linguistic methods were employed in the investigation by recognizing the characteristics of academic language using "multi-dimensional analyses of the overall patterns of register variation" (Biber et al., 2006, p. 129). By making wordlists of the students' texts the text complexity was manually identified looking at the rate of use of nominalizations and verbs in the passive tense (Teleman et al., 2010; SAG 1, p. 201; SAG 2, p. 506). Nominalizations contribute to making texts more explicit, complex and dense as does the use of verbs in the passive tense which depersonalizes a text (cf. Snow \& Ucceli, 2009, p. 119). These grammatical functions are also frequently used in standardized tests and in teaching material (Persson, 2016; Ribeck, 2015). Subject specific language was not possible to classify as no valid corpus was available, the same applies for academic words and specialized vocabulary. Hence the use of low-frequency words in the lexical profiles instead (cf. Nation, 2013). Comparisons with equivalent measurements in texts written in English are not feasible due to differences in the Swedish preference for compounds.

Table 3. Overview of methods of text analyses to explore academic writing.

\begin{tabular}{ll}
\hline Quantitative text analyses by measurement of: & $\begin{array}{l}\text { text length } \\
\text { word length } \\
\text { words longer than six letter } \\
\text { word variation index }\end{array}$ \\
\hline $\begin{array}{ll}\text { Quantitative subject related text analyses to } \\
\text { analyse text complexity: }\end{array}$ & $\begin{array}{l}\text { nominalizations } \\
\text { verbs in the passive tense }\end{array}$ \\
\hline Lexical frequency profiles by analysing: & $\begin{array}{l}\text { high- frequency words } \\
\text { low-frequency words } \\
\text { token coverage of a text }\end{array}$ \\
\hline
\end{tabular}

Statistical analyses of all results have been performed by using the software Statistical Package for the Social Sciences, SPSS version 23. Analysis of Variance (ANOVA) was applied to analyze the variances among group means of the results of the different vocabulary variables and to see the amount of variation. Scheffe's test was used to balance the differences of participants in the three groups and to compare means for more than two groups (Gray \& Kinnear, 2012). The results are reported as means for the CLIL groups at schools A, B and C respectively. In addition, means, standard deviation (SD) and p-values for significance levels between groups are provided in separate tables for each variable. 


\section{Results}

Of the nine variables examined in the 306 texts, four are reported here because of the limited space. The motivation for including text length is that it constitutes a baseline for comparisons to detect possible lexical density in the students' writing regarding the use of nominalizations, verbs in the passive tense and low-frequent words as features of academic writing.

\subsection{Text length}

Text length varied both between the assignments, the individual students and between the three schools. The longest text of all, in the four assignments, was written in assignment 3 by a student from school A (1552 words). The shortest text was written by a student at school B with 89 words in assignment 1, followed by a text in assignment 4 written by a student at school $C$ with 102 words. Thus, the dispersion is wide as further illustrated in table 4.

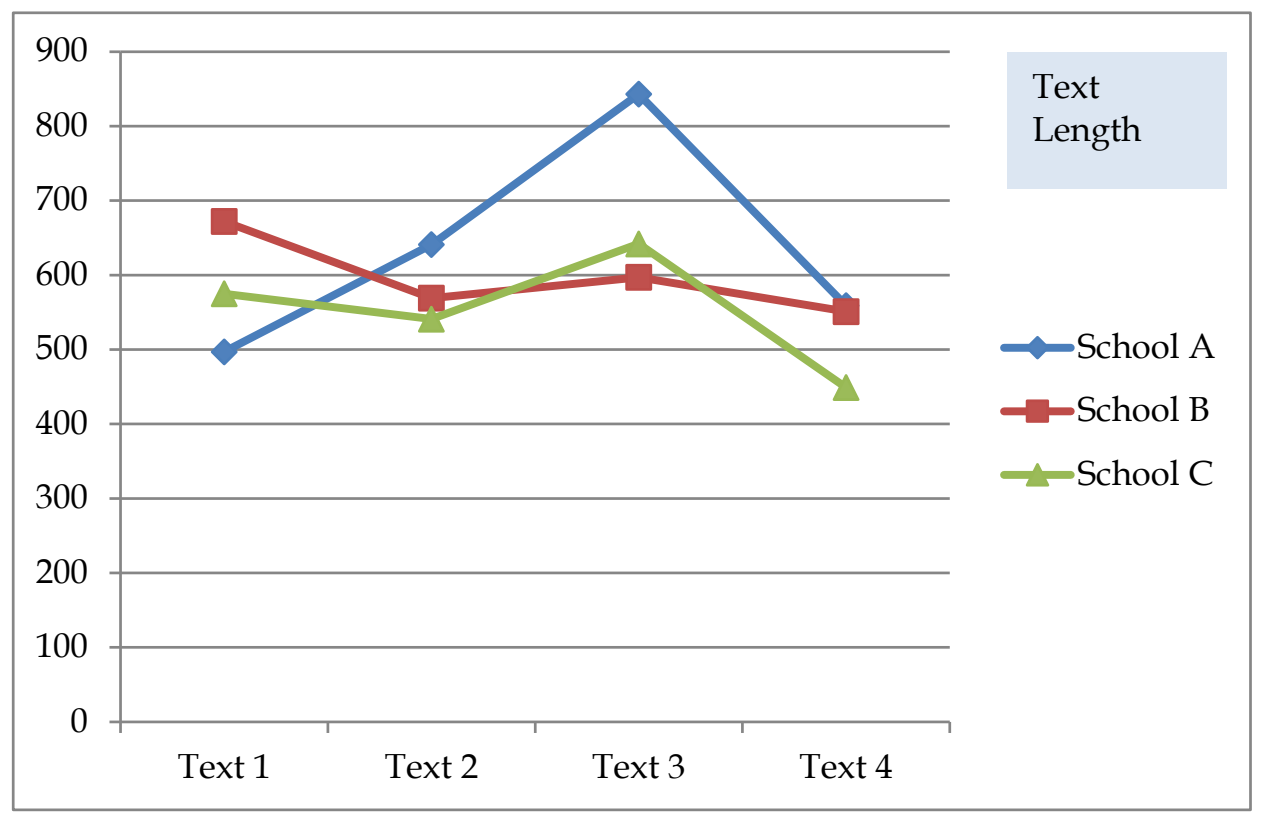

Figure 1. Results Text length, assignments 1, 2, 3 and 4, schools A, B and C.

Table 4 shows the total number of participants, group means and standard deviation from all four assignments on the subject of text length.

Table 4. Results concerning text length for assignment 1, 2, 3, 4 schools A, B and C.

\begin{tabular}{|c|c|c|c|c|c|c|c|c|c|c|c|c|}
\hline \multirow[t]{2}{*}{ School } & $\frac{\text { Assig. }}{\underline{1}}$ & Mean & $\begin{array}{l}\text { Stand. } \\
\text { Dev. } \\
\text { (SD) }\end{array}$ & $\frac{\text { Assig. }}{\underline{2}}$ & Mean & $\begin{array}{l}\text { Stand. } \\
\text { Dev. } \\
\text { (SD) }\end{array}$ & $\frac{\text { Assig. }}{\underline{3}}$ & Mean & $\begin{array}{l}\text { Stand. } \\
\text { Dev. } \\
\text { (SD) }\end{array}$ & $\frac{\text { Assig. }}{\underline{4}}$ & Mean & $\begin{array}{l}\text { Stand. } \\
\text { Dev. } \\
\text { (SD) }\end{array}$ \\
\hline & $\begin{array}{l}\text { Total } \\
\mathrm{N}=80\end{array}$ & & & $\begin{array}{l}\text { Total } \\
\mathrm{N}=84\end{array}$ & & & $\begin{array}{l}\text { Total } \\
\mathrm{N}=75\end{array}$ & & & $\begin{array}{l}\text { Total } \\
\mathrm{N}=67\end{array}$ & & \\
\hline School A & 26 & 497 & 197 & 26 & 641 & 314 & 23 & 843 & 297 & 22 & 559 & 200 \\
\hline School B & 19 & 672 & 237 & 21 & 567 & 125 & 19 & 597 & 216 & 18 & 551 & 149 \\
\hline School C & 35 & 575 & 180 & 37 & 541 & 158 & 33 & 642 & 226 & 27 & 449 & 99 \\
\hline
\end{tabular}


In a further investigation an Analysis of Covariance (ANCOVA) was performed (table 5). Between-Subjects-Effects were investigated and the ANCOVA controls for differences between the groups at the beginning of the period (here text length in assignment 1 - covariance) and evaluates the relative effect of the schools on student development (as measured by text length in assignments 2, 3 and 4 - dependent variable) to make them equal regarding the independent variable (here schools). By relating the results in assignment 1 with results in assignments 2, 3 and 4 and make pairwise comparisons where only the students who participated in assignments 1 and 2, in assignments 1 and 3 , in assignments 1 and 4, were included, the estimated means were adjusted. In each of these pairwise comparisons, significant differences were found in text length development in school $\mathrm{A}$ in comparison with schools $\mathrm{B}$ and $\mathrm{C}$ as is shown in table 5 .

Table 5. Pairwise comparisons concerning text length.

\begin{tabular}{llll}
\hline Pair & Assignment 2, $p$-value & Assignment 3, $p$-value & Assignment 4, $p$-value \\
\hline School A vs school B & $<.001$ & $<.001$ & .088 \\
\hline School A vs school C & $<.001$ & .002 & .004 \\
\hline
\end{tabular}

The texts did not increase in length from year one to year three for the individual students at any of the schools during their upper secondary period.

\subsection{Nominalizations}

The use of this feature is expressed as a percentage of the total number of tokens in the students' texts. The mean for the three groups lies around 1 per cent in all four assignments with small variations between the schools. The maximum results for individuals are shown in assignments 2 and 4 by students from schools B and C. The lowest rates were found for several individuals not using this grammatical tool at all. Table 6 shows the number of participants, group means and standard deviation from all four assignments on the subject of text length.

Table 6. Results concerning nominalizations for assignment 1, 2, 3, 4 schools A, B and C.

\begin{tabular}{|c|c|c|c|c|c|c|c|c|c|c|c|c|}
\hline School & $\frac{\text { Assig. }}{\underline{1}}$ & Mean & $\begin{array}{l}\text { Stand. } \\
\text { Dev. } \\
\text { (SD) }\end{array}$ & $\frac{\text { Assig. }}{\underline{2}}$ & Mean & $\begin{array}{l}\text { Stand. } \\
\text { Dev. } \\
\text { (SD) }\end{array}$ & $\frac{\text { Assig. }}{\underline{3}}$ & Mean & $\begin{array}{c}\text { Stand. } \\
\text { Dev. } \\
\text { (SD) }\end{array}$ & $\frac{\text { Assig. }}{\underline{4}}$ & Mean & $\begin{array}{l}\text { Stand. } \\
\text { Dev. } \\
\text { (SD) }\end{array}$ \\
\hline & $\begin{array}{l}\text { Total } \\
\mathrm{N}=80\end{array}$ & & & $\begin{array}{l}\text { Total } \\
\mathrm{N}=84\end{array}$ & & & $\begin{array}{l}\text { Total } \\
\mathrm{N}=75\end{array}$ & & & $\begin{array}{l}\text { Total } \\
\mathrm{N}=67\end{array}$ & & \\
\hline School A & 26 & 1.14 & .69 & 26 & .80 & .34 & 23 & 1.05 & .66 & 22 & 0.99 & .81 \\
\hline School B & 19 & 1.14 & .86 & 21 & 1.50 & .87 & 19 & 1.25 & .86 & 18 & 1.44 & .80 \\
\hline School C & 35 & 1.07 & .75 & 37 & .97 & .61 & 33 & 0.88 & .78 & 27 & 1.19 & .82 \\
\hline
\end{tabular}

There is no significant between-group difference established in assignments 1,3 or 4 but in assignment 2, Car-free City, the students at school B used more nominalizations than the other two schools and a significant between-group difference was detected $(p=<.001)$. The Scheffe post-hoc test identified that differences existed between schools B and A $(p=<.001)$ and between schools B and $C(p=.006)$. The highest individual use of nominalizations occurs in assignment 3 and 4 by students at school $B$ and $C$ with a use of 3.6 percent. 


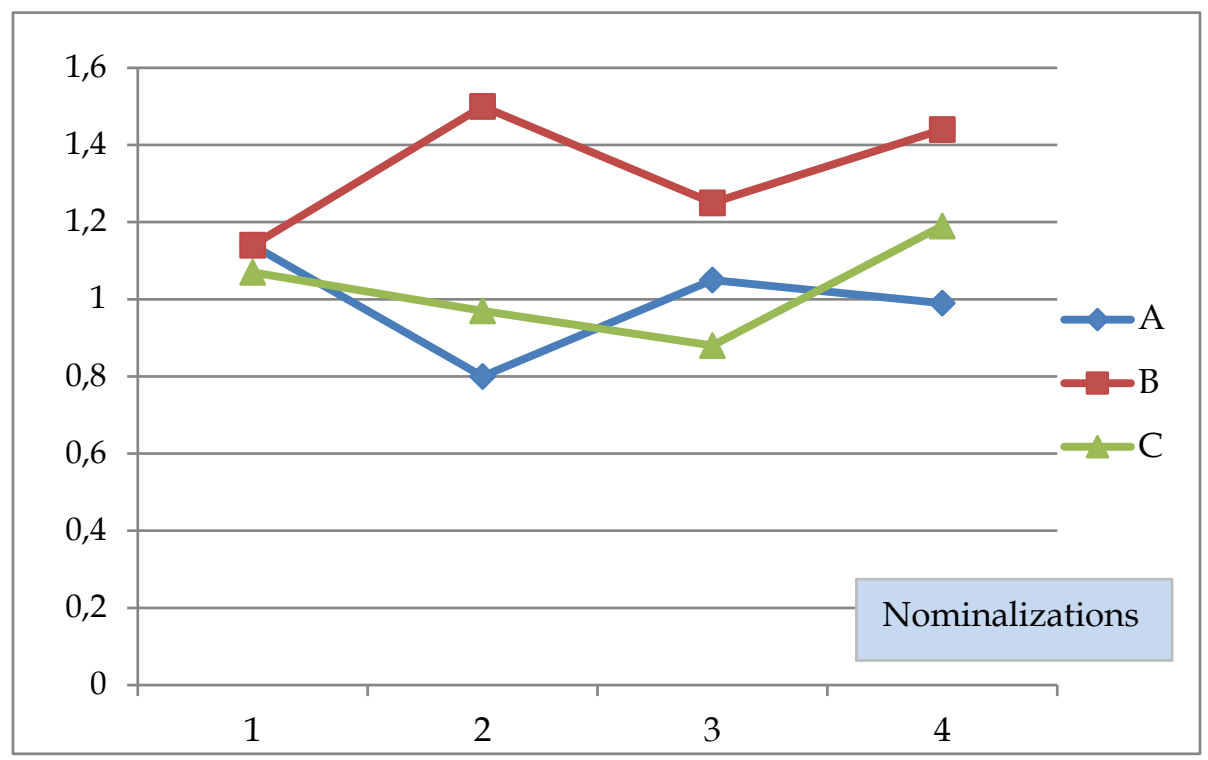

Figure 2. Results Nominalizations in assignments 1, 2, 3 and 4, schools A, B and C.

To summarize the use of nominalizations (percentage of total number of words); it is clear that the use is very low, both as means for the groups and for individual students.

\subsection{Verbs in the passive tense}

The proportion of verbs in the passive tense is expressed as a percentage of the total number of words in the students' texts. The use of the passive is in general very low with means even below 1 percent in all assignments (see figure 3 ). Some individuals show a higher degree of usage, while others do not use the passive tense at all. As with the use of nominalizations this implies that differences between the schools are very small when counting the number of words.

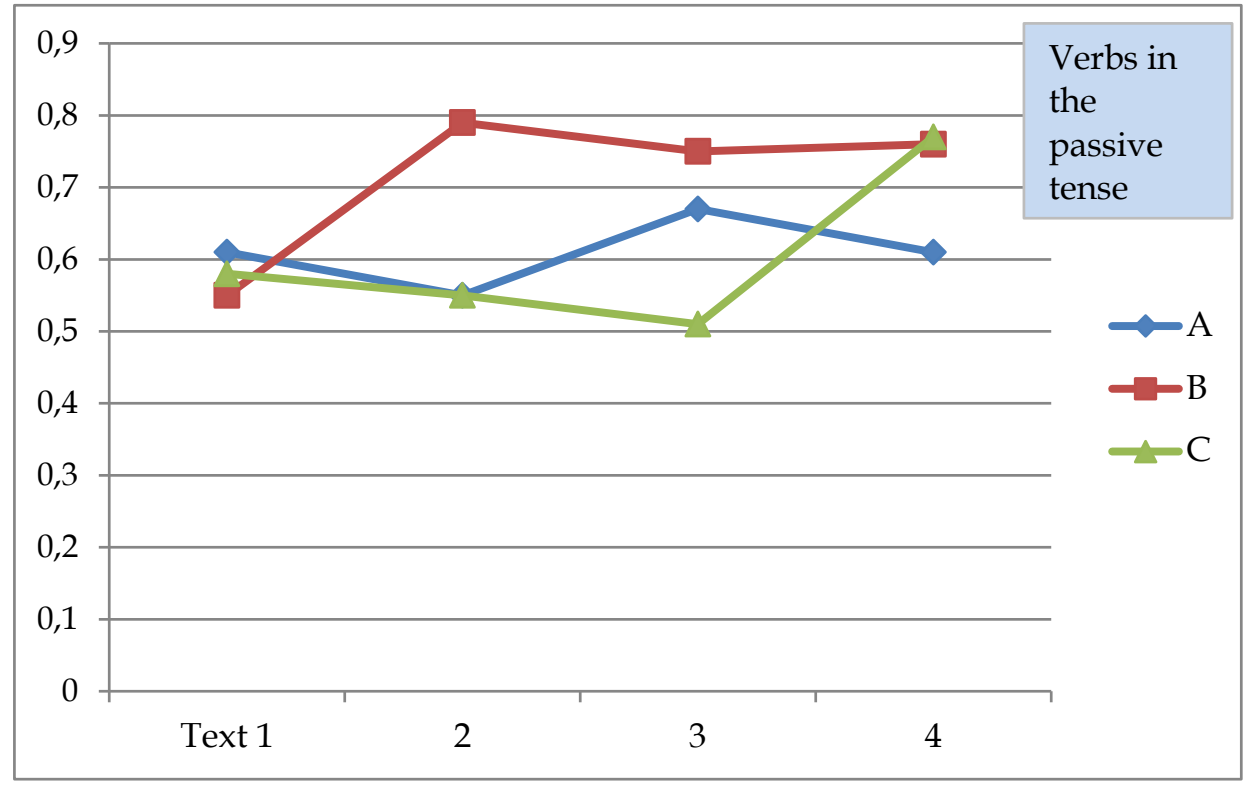

Figure 3. Results Verbs in the passive tense, assignments 1, 2, 3 and 4, schools A, B and C. 
In figure 3, results are visualized as graphs with the average use of verbs in the passive tense for each school and assignment. In table 7 the total number of texts, mean and standard deviation for the four assignments are reported.

Table 7. Results concerning the use of verbs in the passive tense, assignment 1, 2, 3 and 4, schools A, B and C.

\begin{tabular}{|c|c|c|c|c|c|c|c|c|c|c|c|c|}
\hline School & $\begin{array}{c}\underline{\text { A.1 }} \\
\text { Total } \\
\mathrm{N}=80\end{array}$ & Mean & $\begin{array}{c}\text { Stand. } \\
\text { Dev. } \\
\text { (SD) }\end{array}$ & $\begin{array}{c}\underline{\mathrm{A} .2} \\
\text { Total } \\
\mathrm{N}=84\end{array}$ & Mean & $\begin{array}{l}\text { Stand. } \\
\text { Dev. } \\
\text { (SD) }\end{array}$ & $\begin{array}{l}\underline{\mathrm{A} .3} \\
\text { Total } \\
\mathrm{N}=75\end{array}$ & Mean & $\begin{array}{l}\text { Stand. } \\
\text { Dev. } \\
\text { (SD) }\end{array}$ & $\begin{array}{c}\underline{\text { A.4 }} \\
\text { Total } \\
\mathrm{N}=67\end{array}$ & Mean & $\begin{array}{l}\text { Stand. } \\
\text { Dev. } \\
\text { (SD) }\end{array}$ \\
\hline School A & 26 & .612 & .4208 & 26 & .554 & .3265 & 23 & .670 & .5700 & 22 & .609 & .4800 \\
\hline School B & 19 & .553 & .3470 & 21 & .790 & .6534 & 19 & .747 & .5787 & 18 & .756 & .1647 \\
\hline School C & 35 & .577 & .3835 & 37 & .551 & .4279 & 33 & .512 & .3681 & 27 & .770 & .0981 \\
\hline
\end{tabular}

In assignment 1 , there is no significant between-group difference established $(p=.876)$. The same is shown in assignment 2 with no significant difference between the classes $(p=.138)$. In assignment 3 , there is again no significant difference between groups $(p=.221)$ and here too, some students do not use this grammatical tool whatsoever. For the last assignment, the pattern of using verbs in the passive tense is similar; no significance between groups $(p=.564)$, a use between zero and 3.2 per cent. Both schools $B$ and $C$ have a low standard deviation in this assignment, .1647 for school B, .0981 for school C, yielding the lowest SD of all assignments in text 4 . The student with the highest use of verbs in the passive tense in all assignments is from school B with a use of 3.4 percent in assignment 4 .

To summarize, it is clear that the use of verbs in the passive tense is very low (percentage of total number of words), both as means for the groups as for individual students. Some students do not use this grammatical tool at all. Looking at the results for the passive voice in the four different assignments it should be noted that fewer students wrote assignment 4 .

\subsection{Low-frequency words}

Low-frequency words are also called off-list words as they are not included in the frequency bands, here levels 1-5 covering the 5000 most frequent or "common" words in Swedish according to the corpus (Blog mix, Språkbanken, 2012). Lowfrequency words are reported as percentage of the total number of words in the students' texts. This category represents uncommon words, often words with more than six letters and in the students' texts also some subject specific words and a few technical words (cf. Nation, 2013). In figure 4, a lexical profile made for one text is shown as an example of how the low-frequent words are visualized in black (Level 0) in the AntWordProfiler (Anthony, 2014). The text shown in figure 4 illustrates the use of words from different frequencies of which 16.7 percent are low-frequency words. 
Delad föräldrapeng- frihet eller tvång?

Föräldrapenningen är ett hett diskussionsämne. Vissa hävdar att en helt delad föräldrapeng skulle bidra till att göra Sverige mer jämställt medan andra menar att föräldrarna bör få välja själva hur de fördelar tiden med sina barn. Jag anser att båda ståndpunkter har sina fördelar, men allra bäst är nog ett mellanting där en del av tiden är avsatt för vardera förälder medan resten kan fördelas fritt.

Sedan Sverige införde regeln att två månader av de totalt 18 man är berättigad till föräldrapenning ska gå till varje förälder har andelen pappaledighetsdagar ökat nämnvärt. Detta visar på att sådana åtgärder ökar jämställdheten i svenska familjer och främjer ett mer jämställt samhälle över lag, eftersom det till exempel blir lättare för kvinnor att göra karriär när de inte förväntas ta hela barnledigheten själva. Eftersom denna bestämmelse visat så goda resultat vill därför många svenskar nu ta detta ett steg längre och införa en helt delad föräldrapeng med nio månader per förälder.

Detta förslag tror jag dock motverkar grundtanken med jämställdhet. I mina ögon är ett jämställt samhälle ett samhälle där vi genom våra värderingar och handlingar visar att män och kvinnor ska ha samma möljigheter att göra karrär, få en värdig lön o.s.v. Detta kommer vi aldrig att kunna uppnå genom tvång som till exempel att tvinga mammor och pappor att ta ut exakt lika lång ledighet. Då förändras endast föräldrarnas villkor för att de blivit tvungna till det, inte för att deras syn på familjen förändrats.

Inte heller förslaget om total valfrihet när det gäller föräldraledigheten tror Level List Words Non-Level List Words

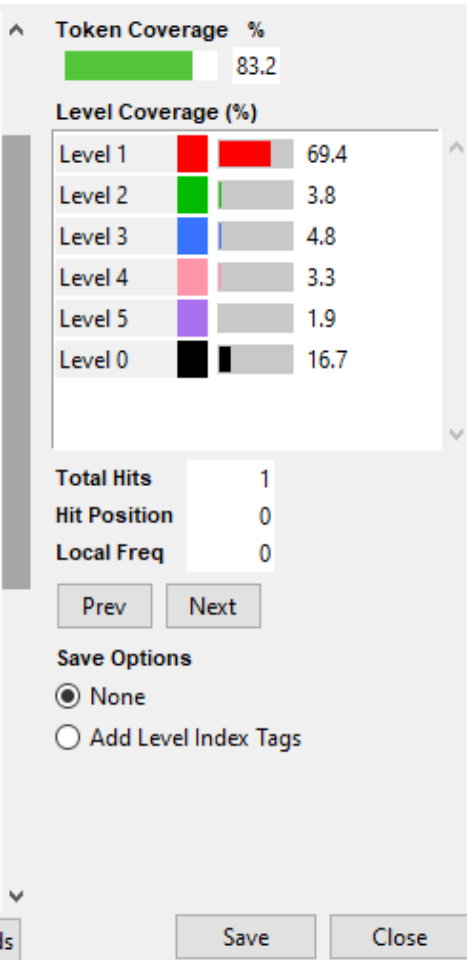

Figure 4. A lexical profile representing one students' text, assignment 4.

Looking at figure 5, the means for off-list words are lower in the last text compared with the first for all schools.

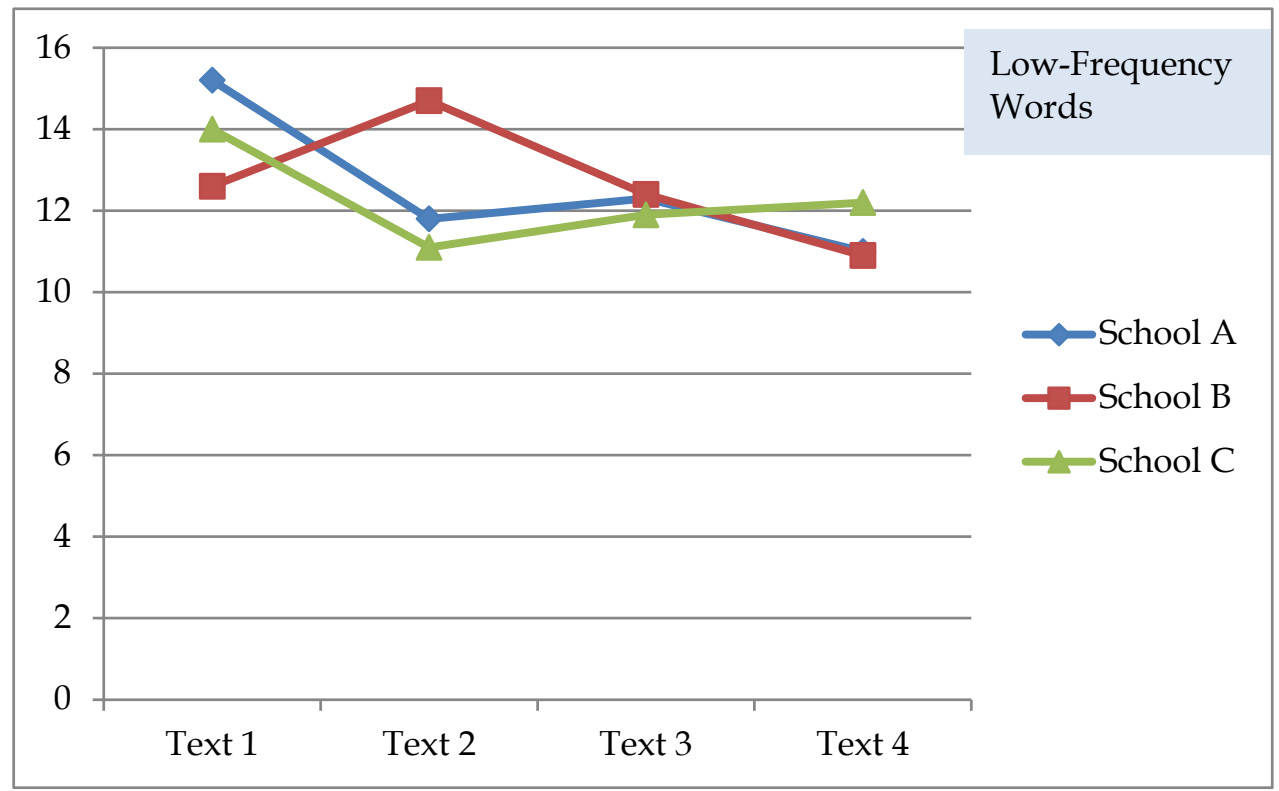

Figure 5. Results for low-frequent words, assignments 1, 2, 3 and 4, schools A, B and C.

In table 8 the total numbers of texts, the mean and SD for the four assignments related to low-frequency words, are reported. Results here show a wide range for the individual students between a minimum $(5.5 \%)$ and the maximum result $(23.7 \%)$. The group means are between $12-15$ percent in all assignments. 
Table 8. Results concerning low-frequency words, assignments 1, 2, 3 and 4, schools A, B and C.

\begin{tabular}{|c|c|c|c|c|c|c|c|c|c|c|c|c|}
\hline School & $\begin{array}{c}\underline{\text { A.1 }} \\
\text { Total } \\
\mathrm{N}=80\end{array}$ & Mean & $\begin{array}{l}\text { Stand. } \\
\text { Dev. } \\
\text { (SD) }\end{array}$ & $\begin{array}{c}\text { A.2 } \\
\text { Total } \\
\mathrm{N}=84\end{array}$ & Mean & $\begin{array}{l}\text { Stand. } \\
\text { Dev. } \\
\text { (SD) }\end{array}$ & $\begin{array}{c}\underline{\mathrm{A} .3} \\
\text { Total } \\
\mathrm{N}=75\end{array}$ & Mean & $\begin{array}{l}\text { Stand. } \\
\text { Dev. } \\
\text { (SD) }\end{array}$ & $\begin{array}{c}\underline{\mathrm{A} .4} \\
\text { Total } \\
\mathrm{N}=67\end{array}$ & Mean & $\begin{array}{l}\text { Stand. } \\
\text { Dev. } \\
\text { (SD) }\end{array}$ \\
\hline School A & 26 & 15,19 & 2,86 & 26 & 11,80 & 3,35 & 23 & 12,30 & 3,55 & 22 & 11,00 & 3,66 \\
\hline School B & 19 & 12,61 & 4,39 & 21 & 14,64 & 3,77 & 19 & 12,40 & 2,51 & 18 & 10,85 & 3,04 \\
\hline School C & 35 & 13,93 & 3,71 & 37 & 11,10 & 3,49 & 33 & 12,14 & 3,57 & 27 & 12,12 & 3,89 \\
\hline
\end{tabular}

In the first assignment, no significant difference between groups was detected ( $p$ $=.068)$. A significant between-group difference was found in assignment $2,(p$ $=.002)$, and the Scheffe post-hoc test identified that differences existed between schools B and A ( $p=.027)$, and between schools B and C $(p=.002)$. The highest result identified in this assignment was for a student at school B $(23.7 \%)$. In the last assignment, there was no statistically significant difference between groups $(p=.420)$.

\section{Discussion}

The aim in this study was to examine the vocabulary use in texts written in L1 Swedish between three participating CLIL schools in relation to their use of L2 English and L1 Swedish in various proportions; school A is an almost monolingual English school whereas schools B and C use English and Swedish in parallel. Hence the research question focusing on possible differences in written L1 use between the three schools offering different types of CLIL provision, regarding linguistic variables connected to academic writing. The use of quantitative analyses in a longitudinal study makes it possible to identify characteristic features of the academic language and also to understand the connection between vocabulary knowledge and other aspects of language proficiency as here in writing (Anthony, 2020, p. 563).

The participating students use the linguistic variables in the examined texts, to more or less the same extent, despite the dissimilar exposure to L2 English and L1 Swedish. The variations between the schools are minor and vary in relation to assignment and individuals. The results of this study suggest that neither of the three schools' individual use of L2 English and L1 Swedish respectively seems to have detrimental effects on students' L1 written vocabulary.

For the quantitative text measurements, results show an almost even variation in the four assignments between schools $A, B$ and $C$, regarding any of the variables examined. The results for the three schools during the three years alternate, which is illustrated in figures 1, 2, 3 and 5 as do the means (tables 4, 6, 7 and 8). A few significant between-group differences are affirmed, though schools A and B generally exhibit higher means in comparison with school C.

It is difficult to detect any evidence of progression in the use of the variables reported on in this article, for any of the schools. Rather, the results seem to be connected to the topics and which individual students participated at the different writing occasions. When significant between-group differences are perceived between the first and the last assignment, they do not correspond to a progression compared to results in assignment 2 and 3 . The results regarding the four variables presented fluctuate between groups and assignments. Looking at covariance, it is visible in figures 1 and 2 how the engagement in the topic Public 
Health (assignment 3), resulted in longer texts, especially for students at school A, but with few low-frequent words as the students wrote more personally and in so doing used more common, high-frequent words rather than low-frequent, uncommon words (Nation, 2013). When doing an ANCOVA, school A where almost only English is used as medium of instruction, stands out regarding text length, with significantly longer texts. Thus, the different scope of English as medium of instruction is not reflected in the students' written vocabulary in their L1 Swedish in the four assignments examined within this study. Quantitative measurement might contribute and give indications of students' knowledge of academic writing but can and should of course not be a sole text assessment tool.

The use of nominalizations and verbs in the passive tense, as an indicator of academic writing and the language of schooling (e.g., Myhill, 2018; Schleppegrell 2004; Teleman et al., 2010), is not something the students seem to have captured as linguistic knowledge when writing these argumentative and expository texts. The students use both nominalizations and the passive tense to a very low degree, some none at all. Linguistic text constructions in teaching materials as well as in test materials (PIRLS, PISA and TIMMS) often exhibit a high usage of these two grammatical constructions. The text analyses in this study indicate that knowledge of what also can be called an academic register (Biber et al., 2006), concerning the variables investigated here is not frequently and consciously used.

Regarding low-frequency words it can be noted that the means for school B in assignment 2, Car-free city, are considerably higher than those for schools A and C. Looking at the individual texts, the engagement in the local community to become a car-free city is shown with many car related, compound words in Swedish (such as bilberoende, bilförbud, bilkörande, bilproduktion) hence long words (six letters or more) and thereby often low-frequent words. School B also peaks in assignment 2 regarding the use of nominalizations and verbs in the passive tense, both also occurring as low-frequent words. It could possibly be interpreted as a contradiction to choose text length as an indicator for academic writing skills in combination with the awareness of how to increase text density. However, comparing the lexical profiles in the study, a high use of low frequent words was related to longer texts. The individuals managing to write fairly long texts with high density are few but represented at all three schools.

A national test essay for one of the classes, school B, was accessible for the CLISS-project to examine and use for comparisons. That essay was a basis for grades in the subject area of Swedish for the students and also written with a longer time limit. Despite that, the results regarding all variables of interest here are lower for that particular class than in the four assignments examined within the present study. This indicates seriousness from the students when writing texts within the CLISS-project.

Different amount of L2 English for the students in this study does not seem to be reflected in their L1 writing skills at word level. The results in the present study confirm that there are variations within the CLIL classes and small variations between the three CLIL classes, but these variations cannot, in this study, be confirmed to relate to the different CLIL models. Nor can the age of onset of the L2 be considered to influence as the participating students are young adults and most of them have encountered English in school from early ages though not as the medium of instruction (cf. Merisuo-Storm, 2006; Murphy et al., 2015). However, the use of English and Swedish as intertwined medium of instruction seems to be beneficial in this study judged by the results where the 
students' L1 written Swedish is relevant and adequate (cf. Lasagabaster \& Garcia, 2014; Navarro-Pablo \& López Gándara, 2019; Nikula \& Moore, 2019; Yoxsimer Paulsrud 2014).

Some of the pedagogical implications provided by the results in this study are that knowledge of linguistic features connected to academic prose and academic register is of utmost importance as these skills are required in the national curriculum (Lgy11) and also in all higher education. A linguistic progression in text writing is expected during a period of three school years, regardless of the age group of students. The reasons why this is not evident in this study can be discussed but more writing in school might be one key, additional reading another, both aiming at text awareness.

The limitations in this study that need to be considered is the number of participants in the different assignments which is not always the same, implying that different individuals' strengths and weaknesses might have had an impact on the results. Further calculations on group level are not possible to do with reliable results due to the small number of participants in the different classes and also the minor variations regarding results for some of the variables investigated. However, other statistical analyses could have been used but the results reported here answer the question if and how, differences in the scope of instruction in L2 English at the three CLIL schools are reflected in the L1 Swedish writing regarding productive academic vocabulary in students' texts. Another aspect to consider is that the study presents quantitative results regarding L1 writing, qualitative aspects connected to academic prose are thereby not included. Nonetheless, corpus linguistic tools are frequently used to understand writing and vocabulary though not so often in didactic research (Anthony, 2020; Schmitt, 2010).

\section{Concluding remarks}

The results regarding L1 writing in 306 texts examined and analyzed here, indicate that the differences in the scope of instruction in L2 English in the three CLIL schools do not seem to be related to the L1 Swedish in the students' written texts. The quantitative investigations show a low use of characteristic linguistic variables associated with academic prose, here exemplified by nominalizations and verbs in the passive tense. This points to a need for further attention on language development regarding academic writing and the understanding and acquisition of its specific features. However, in a study prior to this (see Ohlsson, 2018) where comparisons were made with non-CLIL classes, the same results were obtained. This indicates that, regardless of the medium of instruction, a greater focus should be placed on linguistic awareness when writing in school.

The three participating upper secondary schools; A, B and C represent diverse CLIL models and as there are no regulations around CLIL in Sweden, further research regarding this form of education is called for. In Sweden education is free and at this level selection is obtained only by grades. The students in this study come from different backgrounds but they are motivated and they use a variety of languages in their communication. In addition, more and complementary CLIL research on L1 is needed with both a receptive and productive focus with homogenous groups, both CLIL and non-CLIL to include SES factors. The results of this study, however, should hopefully contribute to limiting the fear regarding L1 writing skills worsening in CLIL education in the Swedish CLIL context. 


\section{Endnotes}

1 The Swedish Research Council (Vetenskapsrådet), 2011-2014, No: 721-2010-5376

2 https://www.lix.se/

${ }^{3}$ https://www.laurenceanthony.net/software/antwordprofiler/

\section{References}

Anthony, L. (2014). AntWordProfiler (Version 1.4.0) [Computer Software]. Waseda University. http://www.laurenceanthony.net/software/antwordprofiler

Anthony, L. (2020). Resources for researching vocabulary. In S. Webb (Ed.), The Routledge handbook of vocabulary studies (pp. 561-590). Routledge.

Apelgren, B.-M. (2018). Höga betyg in, höga betyg ut: En studie om betygsutveckling hos elever med engelska som undervisningsspråk [High grades from start to finish. A study of grade development among students with English as the medium of instruction]. Skolverket.

Apelgren, B.-M. (2019). The CLISS student: Some background factors of the participating students in the CLISS project. In L. K. Sylvén (Ed.), Investigating content and language integrated learning: Insights from Swedish high schools (pp. 35-53). Multilingual Matters.

Apelgren, B.-M., \& Holmberg, P. (2018). På spaning efter progression. En studie av textstruktur i gymnasieelevers uppsatser på svenska och engelska [A study of text structure in high school students' essays in Swedish and English]. Skolverket.

Biber, D., Conrad, S., \& Reppen, R. (2006). Corpus linguistics. Investigating language structure and use (5th ed.). Cambridge University Press.

Bruton, A. (2015). CLIL: Details matters in the whole picture. More than a reply to J. Hüttner and U. Smit (2014). System 53, 119-128. https://doi.org/10.1016/j.system.2015.07.005

Carter, R., \& McCarthy, M. (2006). Cambridge grammar of English. Cambridge University Press.

Cenoz, J., Genesee, F., \& Gorther, D. (2014). Critical analysis of CLIL: Taking stock and looking forward. Applied Linguistics, 35(3), 243-262. https://doi.org/10.1093/applin/amt011

Commission of the European Communities. (COM/2003/449). Promoting language learning and linguistic diversity: An action plan 2004-2006. https://op.europa.eu/en/publicationdetail/-/publication/b3225824-b016-42fa-83f6-43d9fd2ac96d

Coyle, D. (2005). CLIL. Planning tools for teachers. http://docplayer.net/35310909-Clilplanning-tools-for-teachers-4cs-curriculum-guidance-3as-lesson-planning-tool-matrixaudit-tool-for-tasks-materials.html

Coyle, D. (2007). Content and language integrated learning: Towards a connected research agenda for CLIL pedagogies. International Journal of Bilingual Education and Bilingualism, 10(5), 543-562. https://www.tandfonline.com/doi/abs/10.2167/beb459.0

Dalton-Puffer, C. (2007). Discourse in content and language integrated learning (CLIL) classrooms. John Benjamins Publishing Company.

Dalton-Puffer, C. (2011). Content-and-language integrated learning: From practice to principles? Annual Review of Applied Linguistics, 31, 182-204. https://doi.org/10.1017/ $\underline{\mathrm{S} 0267190511000092}$

Dalton-Puffer, C., Linares, A., Lorenzo, F., \& Nikula, T. (2014). “You can stand under my umbrella": Immersion, CLIL and bilingual education. A response to Cenoz, Genesee \& Gorter 2013. Applied Linguistics, 35(2), 213-218. https://doi.org/10.1093/applin/amu010

de Dios Martinez Agudo, J. (2020). To what extent does parental educational background affect CLIL learners' content subject learning? Evidence from research in Spain. International Journal of Bilingual Education and Bilingualism. https://doi.org/10.1080/ $\underline{13670050.2020 .1715916}$

Fang, Z., \& Park, J. (2019). Adolescents' use of academic language in informal writing. Reading and Writing, 33, 97-119. https://doi.org/10.1007/s11145-019-09937-8

Government Bill. (1989/90:41). Regeringens proposition om kommunalt huvudmannaskap [The Government's bill on municipal leadership]. https://data.riksdagen.se/fil/A64696E0830E-4FCB-8001-C62E8D4234BC 
Government Bill. (1992/93:220). En ny läroplan för grundskolan och ett nytt betygssystem för grundskolan, sameskolan, specialskolan och den obligatoriska särskolan [A new curriculum for compulsory school and a new grading system for compulsory school, Sami school, special school and the compulsory special school]. https://lagen.nu/prop/1992/93:220

Gray, C. D., \& Kinnear, P. R. (2012). IBM SPSS statistics 19 made simple. Psychology Press.

Holmberg, P. (2019). The development of academic vocabulary in Swedish. In L. K. Sylvén (Ed.), Investigating content and language integrated learning: Insights from Swedish high schools (pp. 173-186). Multilingual Matters.

Johansson, S., \& Ohlsson, E. (2019). Visualizing vocabulary: An investigation into student assignments in CLIL and non-CLIL contexts. In L. K. Sylvén (Ed.), Investigating content and language integrated learning: Insights from Swedish high schools, (pp. 216-235). Multilingual Matters.

Lasagabaster D. (2017). "I always speak English in my classes": Reflections on the use of the L1/L2 in English-medium instruction. In A. Llinares, \& T. Morton (Eds.), Applied linguistics perspectives on CLIL (pp. 251-267). John Benjamins Publishing Company.

Lasagabaster, D., \& Garcia, O. (2014). Translanguaging: Towards a dynamic model of bilingualism at school / Translanguaging: Hacia un modelo dinámico de bilingüismo en la escuela. Cultura y Educación, 26(3), 557-572. https://doi.org/10.1080/11356405.2014.973671

Lim Falk, M. (2008). Svenska i engelskspråkig skolmiljö: Ämnesrelaterat språkbruk $i$ två gymnasieklasser. [Swedish in an English-language school environment: Subject-based language use in two upper secondary classes] (Doctoral dissertation). Stockholm University.

Lim Falk, M. (2015). English and Swedish in CLIL student texts. The Language Learning Journal, 43(3), 304-318. https://doi.org/10.1080/09571736.2015.1053280

Lim Falk, M. (2019). The development of linguistic correctness in CLIL and Non-CLIL students' writing in the L1 at upper secondary school. In L. K. Sylvén (Ed.), Investigating content and language integrated learning: Insights from Swedish high schools (pp. 187-215). Multilingual Matters.

Lim Falk, M., \& Holmberg, P. (2016). Paths to academic writing in a globalized world. A longitudinal study of content and language integrated education in upper secondary school in Sweden. In C. Bazerman, et al. (Eds.). Writing research across borders (pp. 187-211). The Writing across the Curriculum Clearinghouse.

Lin, A. M. Y. (2015). Conceptualizing the potential role of L1 in CLIL. Language, Culture and Curriculum, 28(1), 74-89. https://doi.org/10.1080/07908318.2014.1000926

Lindberg, I., \& Johansson, S. (2019). The development of Swedish receptive vocabulary in CLIL: A multilingual perspective. In L. K. Sylvén (Ed.), Investigating content and language integrated learning: Insights from Swedish high schools (pp. 236-258). Multilingual Matters.

Lorenzo, F., Granados, A., \& Rico, N. (2021). Equity in bilingual education: Socioeconomic status and content and language integrated learning in monolingual Southern Europe. Applied Linguistics, 42(3), 393-413. https://doi.org/10.1093/applin/amaa037

Martínez-Adrián, M., Gutiérrez-Mangado, M. J., \& Gallardodel- Puerto, F. (2019). Introduction: L1 use in content-based and CLIL settings. International Journal of Bilingual Education and Bilingualism, 22(1), 1-4. https://doi.org/10.1080/13670050.2018.1508279

McEnery, T., Xiao, R., \& Tono, Y. (2006). Corpus-based Language Studies. Routledge Applied Linguistics.

Merisuo-Storm, T. (2006). Development of boys' and girls' literacy skills and learning attitudes in CLIL education. In S. Björklund, K. Mård-Miettinen, M. Bergström, \& M. Södergård (Eds.), Exploring dual-focused education. Integrating language and content for individual and societal needs (pp. 176-188). Vaasa University.

Murphy, V. A., Macaro, E., Alba, S., \& Cipolla, C. (2015). The influence of learning a second language in primary school on developing first language literacy skills. Applied Psycholinguistics 36, 1133-1153. https://doi.org/10.1080/13670050.2018.1508279

Myhill, D. (2018). Grammar as a meaning-making resource for improving writing. Contribution to a special issue: Working on Grammar at School in L1-Education: Empirical Research across Linguistic Regions. L1-Educational Studies in Language and Literature, 18, 1-21. https:// doi.org/10.17239/L1ESLL-2018.18.04.04

Nation, P. (2013). Learning Vocabulary in Another Language. (2nd ed). Cambridge University Press. 
Nation, P., \& L. Anthony. (2016). Measuring vocabulary size. In E. Hinkel (Ed.), Handbook of research in second language teaching and learning (pp. 355-368). Routledge.

Navarro-Pablo, M., \& Lopés Gándara, Y. (2019). The effects of CLIL on L1 competence in monolingual contexts. The Language Learning Journal, 48(1), 18-35. https://doi.org/10.1080/ $\underline{09571736.2019 .1656764}$

Navés, T. (2009). Effective content and language integrated learning (CLIL) programmes. In Y. Ruiz de Zarobe, \& R. M. J. Catalán (Eds.), Content and language integrated learning: Evidence from research in Europe (pp. 22-40). Multilingual Matters.

Nikula, T., Dalton-Puffer, C., \& Llinares, A. (2013). CLIL classroom discourse. Research from Europe. Journal of Immersion and Content-Based-Language Education, 1(1), 70-100. https:// doi.org/10.1075/jicb.1.1.04nik

Nikula, T., \& P. Moore. (2019). Exploring translanguaging in CLIL. International Journal of Bilingual Education and Bilingualism, 22(2), 237-249. https://doi.org/10.1080/ $\underline{13670050.2016 .1254151}$

Ohlsson, E. (2018). Att synliggöra vokabulär. En kvantitativ studie av gymnasieelevers skrivuppgifter på svenska inom CLISS-projektets ram [Visualizing vocabulary, an investigation of student assignments in CLIL and non-CLIL context]. Licentiatuppsats, Institutionen för svenska språket. Göteborgs universitet. https://gupea.ub.gu.se/handle/2077/55024

Ohlsson, E. (2021). Den synliggjorda vokabulären och praktiken: Gymnasieelevers akademiska skrivande på svenska [The visualized vocabulary and the practice: Upper secondary students' academic writing in Swedish]. (Doctoral dissertation). University of Gothenburg.

Olsson, E. (2015). Progress in English academic vocabulary use in writing among CLIL and non-CLIL students in Sweden. Moderna Språk, 109(2), 51-74.

Olsson, E. (2016). On the impact of extramural English and CLIL on productive vocabulary (Doctoral dissertation). University of Gothenburg.

Olsson, E., \& Sylvén, L. K. (2015) Extramural English and academic vocabulary. A longitudinal study of CLIL and non-CLIL students in Sweden. Apples - Journal of Applied Language Studies, 9(2), 77-103. https://doi.org/10.17011/apples/urn.201512234129

Olsson, E., \& Sylvén, L. K. (2018). Vad hände sedan? En uppföljningsstudie av elever $i$ CLISS-projektet [What happened? A follow-up study of students in the CLISS project]. Skolverket.

Olsson, E., \& Sylvén, L. K. (2019). English productive proficiency. In L. K. Sylvén (Ed.), Investigating content and language integrated learning: Insights from Swedish high schools (pp. 117-135). Multilingual Matters.

Pavón Vázquez, V., \& Ramos Ordóñez, M. D. C. (2019). Describing the use of the L1 in CLIL: An analysis of L1 communication strategies in classroom interaction. International Journal of Bilingual Education and Bilingualism, 22(1), 34-48. https://doi.org/10.1080/ $\underline{13670050.2018 .1511681}$

Pérez-Canãdo, M. L. (2012). CLIL research in Europe: Past, present, and future. International Journal of Bilingual Education and Bilingualism, 15(3), 315-341. https://doi.org/10.1080/ $\underline{13670050.2011 .630064}$

Pérez Cañado, M. L. (2018). The effects of CLIL on L1 and content learning: Updated empirical evidence from monolingual contexts. Learning and Instruction 57, 18-33. https:// doi.org/10.1016/j.learninstruc.2017.12.002

Pérez Cañado, M. L. (2020). Common CLIL (mis)conceptions: Setting the record straight. In N. Barranco-Izquierdo, M. T. Calderón-Quindós, \& T. Eisenrich (Eds.), The manifold nature of bilingual education (pp. 1-30). Cambridge Scholars Publishing.

Persson, T. (2016). De naturvetenskapliga ämnesspråken: De naturvetenskapliga uppgifterna i och elevers resultat från TIMSS 2011 ar 8 [The subject languages of science education: The science items and students' results from TIMSS 2011 year 8] (Doctoral dissertation). Uppsala University.

Ribeck, J. (2015). Steg för steg. Naturvetenskapligt ämnesspråk som räknas [Step by step. A computational analysis of Swedish textbook language] (Doctoral dissertation). University of Gothenburg.

Ruiz de Zarobe, Y. (2013). CLIL implementation: From policy-makers to individual initiatives. International Journal of Bilingual Education and Bilingualism, 16(3), 231-243. https://doi.org/10.1080/13670050.2013.777383 
Schleppegrell, M. J. (2004). The language of schooling. A functional linguistics perspective. Routledge. Schmitt, N. (2010). Researching vocabulary: A vocabulary research manual. Palgrave Macmillan.

Snow, C. E. (2010). Academic language and the challenge of reading for learning about science. Science, 328, 450-452.

Snow, C. E., \& Ucelli, P. (2009). The challenge of academic language. In D. R. Olson, \& N. Torrance (Eds.), The Cambridge handbook of literacy (pp. 112-133). Cambridge University Press.

SFS. (2009:600). Språklag [Language law]. https://www.riksdagen.se/sv/dokument-lagar/ dokument/svensk-forfattningssamling/spraklag-2009600_sfs-2009-600

SOU. (2002:27). Mål i mun - Förslag till handlingsprogram för det svenska språket [Proposal for an action program for the Swedish language]. Kulturdepartementet. https://www.regeringen. se/rattsliga-dokument/statens-offentliga-utredningar/2002/04/sou-200227/

Språkbanken. (2012). Blog mix [corpus]. https://spraakbanken.gu.se/swe/resurs/bloggmixodat

Sundqvist, P. (2009). Extramural English matters: Out-of-school English and its impact on Swedish ninth-graders' oral proficiency and vocabulary (Doctoral dissertation). Karlstad University.

Swain, M., \& Lapkin, S. (1981). Bilingual education in Ontario: A decade of research. Ontario Institute for Studies in Education.

Swedish National Agency for Education. (1997). Uppdrag rörande utbildning och undervisning på främmande språk [Assignments concerning education and teaching in foreign languages]. Skolverket.

Swedish National Agency for Education. (2000). SPRINT: Språk- och innehållsintegrerad inlärning och undervisning [CLIL: Content and language integrated learning and teaching]. Skolverket.

Swedish National Agency for Education. (2001a). Quality in SPRINT: Towards quality assessment and assurance in content and language integrated education. Skolverket.

Swedish National Agency for Education. (2001b). SPRINT - hot eller möjlighet? [A threat or a possibility?]. Skolverket.

Swedish National Agency for Education. (2011) Läroplan, examensmål och Gymnasiegemensamma mål för gymnasieskola 2011, Lgy11 [Curriculum and syllabi for upper secondary school]. Skolverket. http:// www.skolverket.se/publikationer?id=2705

Swedish National Agency for Education. (2018). Engelskspråkig undervisning [English language teaching]. Skolverket.

Sylvén, L. K. (2004). Teaching in English or English Teaching? On effects on content and language integrated learning on Swedish learner's incidental vocabulary acquisition (Doctoral dissertation). University of Gothenburg.

Sylvén, L. K. (2013). CLIL in Sweden - Why does it not work? A metaperspective on CLIL across contexts in Europe. International Journal of Bilingual Education and Bilingualism, 16(3), 301-320. https:// doi.org/10.1080/13670050.2013.777387

Sylvén, L. K. (2018). Internationell jämförelse av engelskspråkig undervisning i fem länder, Finland, Nederländerna, Tyskland, Spanien och Sverige [International comparison of English-language teaching in five countries, Finland, the Netherlands, Germany, Spain and Sweden]. Skolverket.

Sylvén, L. K. (Ed.). (2019). Investigating content and language integrated learning: Insights from Swedish high schools. Multilingual Matters.

Teleman, U., Hellberg, S., \& Andersson, E. (2010). Svenska Akademiens Grammatik [The Swedish Academy's Grammar] (3rd ed). Norstedts.

Uccelli, P., Galloway Philips, E., Barr, C., Menese, A., \& Dobbs, C. (2015). Beyond vocabulary: Exploring cross-disciplinary academic-language proficiency and its association with reading comprehension. Reading Research Quarterly, 50(3), 337-356. https://doi.org/10.1002/rrq.104

Washburn, L. (1997). English Immersion in Sweden: A case study of Röllingby high school, 19871989 (Doctoral dissertation). Stockholm University.

Yi Lo, Y. (2015). How much L1 is too much? Teacher's language use in response to students' abilities and classroom interaction in content and language integrated learning. International Journal of Bilingual Education and Bilingualism, 18(3), 270-288. https://doi.org/10.1080/13670050.2014.988112 
Yoxsimer Paulsrud, BA. (2014). English medium instruction in Sweden: Perspectives and practices in two upper secondary schools (Doctoral dissertation). Stockholm University.

Yoxsimer Paulsrud, BA. (2019). Mapping CLIL in Sweden. In L. K. Sylvén (Ed.), Investigating content and language integrated learning: Insights from Swedish high schools (pp. 19-34). Multilingual Matters.

Received September 23, 2020 